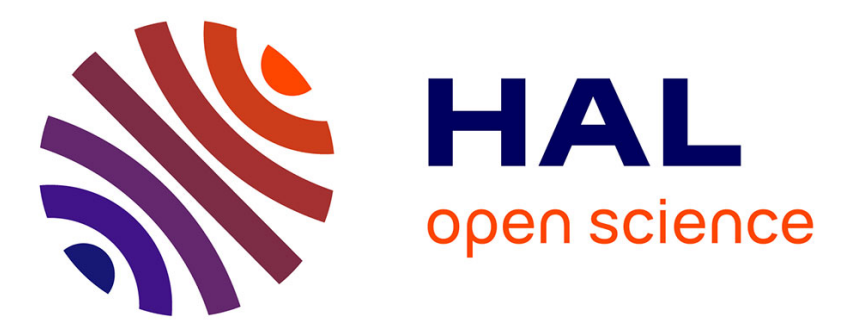

\title{
An Arbuscular Mycorrhizal Fungus (Glomus mosseae) Induces a Defence-like Response in Rubber Tree (Hevea brasiliensis) Roots
}

Isabelle Laffont-Schwob, Huguette Sallanon, Mireille M. Ducher, Alain Coudret

\section{To cite this version:}

Isabelle Laffont-Schwob, Huguette Sallanon, Mireille M. Ducher, Alain Coudret. An Arbuscular Mycorrhizal Fungus (Glomus mosseae) Induces a Defence-like Response in Rubber Tree (Hevea brasiliensis) Roots. Journal of Plant Physiology, 2000, 156, pp.284 - 287. hal-02095618

\section{HAL Id: hal-02095618 https://hal-amu.archives-ouvertes.fr/hal-02095618}

Submitted on 10 Apr 2019

HAL is a multi-disciplinary open access archive for the deposit and dissemination of scientific research documents, whether they are published or not. The documents may come from teaching and research institutions in France or abroad, or from public or private research centers.
L'archive ouverte pluridisciplinaire HAL, est destinée au dépôt et à la diffusion de documents scientifiques de niveau recherche, publiés ou non, émanant des établissements d'enseignement et de recherche français ou étrangers, des laboratoires publics ou privés. 


\title{
Short Communication
}

\section{An Arbuscular Mycorrhizal Fungus (Glomus mosseae) Induces a Defence-like Response in Rubber Tree (Hevea brasiliensis) Roots}

\author{
Isabelle Schwob $^{1 *}$, Mrreille Ducher ${ }^{2}$, and Alain Coudret ${ }^{2}$ \\ ${ }^{1}$ Laboratoire Dynamique et Ressources du Végétal, Université de Provence case 17, 3 place Victor Hugo, F-13331 \\ Marseille cedex 3, France \\ ${ }^{2}$ Laboratoire de Physiologie et Biotechnologies Végétales, Université Blaise Pascal, 24 avenue des Landais, 63177 Aubière \\ cedex, France
}

Received March 1, $1999 \cdot$ Accepted (Revised) September 10, 1999

\section{Summary}

The specific activities of cinnamyl alcohol dehydrogenase (EC 1.1.1.-) and cell wall-bound peroxidases (EC 1.11.1.-) were enhanced in roots of Hevea brasiliensis 2 weeks after inoculation with Glomus mosseae, simultaneously with an increased lignin content. However, no scopoletin accumulation was observed by this time. These defence-like reactions were caused by the first penetration of the AM fungus but they were transient.

Key words: Glomus mosseae, Hevea brasiliensis (rubber tree), lignification, mycorrhization, scopoletin.

Abbreviations: $\mathrm{AM}=$ arbuscular mycorrhizal; $\mathrm{CAD}=$ cinnamyl alcohol $\mathrm{NADPH}$ dehydrogenase; $\mathrm{PO}=$ cell wall-bound peroxidases.

\section{Introduction}

The formation of a functional symbiosis involves a complex sequence of interactions between fungal hyphae and plant root cells (Harrison and Dixon, 1993) Unlike pathogenic biotrophs, which generally elicit typical defence responses in host plants, AM fungi do not induce a lasting response (Codignola et al., 1989; Volpin et al., 1994), acting only transiently during the early stage of colonization (Spanu and Bonfante-Fasolo, 1988; Morandi et al., 1984).

An analysis of data collected on $H$. brasiliensis infected with Rigidoporus lignosus and Phellinus noxius suggests that lignification is important in tree defence (Nicole et al., 1986, 1992). The enzymes specifically involved in the lignin process include cinnamyl alcohol NADPH dehydrogenase (CAD). However, the role of this enzyme in the first steps of mycorrhization is

* To whom correspondence should be addressed. not well documented. Cell wall-bound peroxidases (PO) catalyse phenol oxidation in the cell walls to polymerize lignin precursors.

Isoflavonoid phytoalexins are antimicrobial phenylpropanoid derivatives that often accumulate rapidly in plant tissues resistant to pathogen attack (see Dixon et al., 1995; Smith, 1996). In the rubber tree, scopoletin is a coumarin induced by pathogenic fungi and identified as a phytoalexin (Giesemann et al., 1986; Garcia et al., 1995).

Glomus mosseae forms mycorrhizae with Hevea brasiliensis roots under controlled conditions (Schwob et al., 1998). No study has apparently been conducted on the first enzymatic phenomena occurring in the early stages of AM colonization in rubber tree roots. Our purpose was to ascertain whether a transient host defence response occurs in $H$. brasiliensis roots during G. mosseae installation. $\mathrm{CAD}$ and $\mathrm{PO}$ activities were monitored, and scopoletin and lignins were quantified during the early stages of colonization. 


\section{Materials and Methods}

\section{Plant culture and fungus inoculation}

Surface-sterilized seeds of Hevea brasiliensis Müll. Arg. were pregerminated 2 weeks in sand soil and transplanted into individual 250-mL pots, each containing twice-sterilized sand and peat soil (1/1, $\mathrm{v} / \mathrm{v}), \mathrm{pH}$ 6.2. Plants were grown in a phytotron $(16 \mathrm{H} / 8$ day/night cycle and $27 \pm 1 / 24 \pm 1^{\circ} \mathrm{C}$ day/night temperature at $250 \mu \mathrm{mol} \mathrm{m}^{-2} \mathrm{~s}^{-1}$ daylight [Mazdafluor]). Leek (Allium porrum L.) was used as a source of inoculum of Glomus mosseae (Nicol. \& Gerd.) Gerd. \& Trappe. Each pot with a 2-week-old plant was inoculated by adding $10 \mathrm{~g}$ of soil containing propagules of mycorrhized leek. Control plants were inoculated with $10 \mathrm{~g}$ of twice-sterilized soil containing propagules. Each pot initially received $50 \mathrm{~mL}$ of Long Ashton solution (Hewitt, 1966) with $130 \mu \mathrm{mol} / \mathrm{L}$ phosphorus. Plants were allowed to grow for a maximum of 5 weeks. The root samples were collected each week after inoculation for 5 weeks. Part of the roots were frozen in liquid nitrogen and stored at $-80^{\circ} \mathrm{C}$ until required for the enzyme and scopoletin assays. The rest were dried for the lignin assay.

\section{Visualisation of colonisation}

The course of infection was visualized employing $0.05 \%$ trypan blue in lactophenol (Merck) as described by Phillips and Hayman (1970) after clearing for $10 \mathrm{~min}$ in $10 \% \mathrm{KOH}$ at $90^{\circ} \mathrm{C}$.

\section{Enzyme extraction and assay}

All of the enzyme assays were performed on crude extracts.

CAD (EC 1.1.1.-) activity was assayed as previously described (Sarni et al., 1984). Oxidation of coniferyl alcohol to coniferyl aldehyde was measured by increasing absorbance at $\mathrm{A} 400 \mathrm{~nm}$ at $30^{\circ} \mathrm{C}$. Enzyme activity was expressed in nkat $\mathrm{mg}^{-1}$ protein. PO (EC 1.11.1.-) activity was assayed as previously described (De Jaegher, 1986) by measuring the variation of absorbance at $A 530 \mathrm{~nm}$ after $4 \mathrm{~min}$ at room temperature. Enzyme activity was expressed in $\Delta(\mathrm{OD}) \mathrm{mg}^{-1} \mathrm{~min}^{-1}$ protein.

Three replications of 4 measurements were done for each sample. Protein was determined by the Bradford method (1976) using BSA as standard.

\section{Lignin contents}

Lignin contents were determined on fresh roots, on the cell wall residue obtained after successive extractions of the air-dried and ground wood. The method of De Jaegher et al. (1985), used to prepare cell wall material, was modified by replacing, for safery, benzene by toluene as recommended by Monties (1989). The final preparation was dried at $80^{\circ} \mathrm{C}$. Klason lignin content was estimated as described by Kirk and Obst (1988). Lignins were expressed as a percentage of the original sample.

\section{Scopoletin assay}

Scopoletin was extracted from rubber tree roots by two-dimensional chromatography as described by Mabry et al. (1970) modified by Garcia et al. (1995). Fresh ground roots were extracted at room temperature for 3 days in methanol $(75 \mathrm{~mL})$. After the plant material was removed by filtration, the extract was evaporated to dryness using a water pump vacuum in a rotary evaporator (Rotavapor, Flawil, Schweiz). The residue was dissolved in $1 \mathrm{~mL}$ of methanol. A 20$\mu \mathrm{L}$ aliquot of the solution was spotted on cellulose plates without fluorescent indicator (Merck). A first migration was done in a tertiary butanol : glacial acetic acid: water $(4 / 1 / 5, v / v / v)$ solution. After migration, the chromatogram was dried. A second migration was done in $2 \%$ glacial acetic acid solution. The chromatogram was viewed in UV light $(254 \mathrm{~nm})$ with the help of a trans-illuminator (Polylabo, Strasbourg, France). Spots of scopoletin were isolated and immediately eluted in $2 \mathrm{~mL}$ methanol at room temperature. The remaining gel was removed by centrifuging at $2,000 \mathrm{~g}_{\mathrm{n}}$ for $5 \mathrm{~min}$. The supernatant was analysed by spectrophotometry (spectrophotometer SECOMAN 70) at A $365 \mathrm{~nm}$ using pure commercial scopoletin (Merck) as standard (Giesemann et al., 1986). Scopoletin content was calculated for each sample compared with standard and expressed as a percentage of the original sample.

\section{Statistical analysis}

To test the main and interactive effects of the sampling time ( 1 to 5 weeks) and the inoculation (control or inoculated), data were processed by two-way analysis of variance (ANOVA) (SYSTAT, Deltasoft), and means were compared with Scheffe's test.

\section{Results and Discussion}

\section{Fungal colonization}

One week after inoculation, no external mycelium was visible in the root system of the inoculated plants. After 2 weeks, the first external mycelia were observed, and thereafter external and internal mycelia were present in roots of the inoculated plants. After 5 weeks, few hyphae were visible with some arbuscules, but no vesicules were present, demonstrating that mycorrhization was not fully expanded but developing. The control plants remained uncolonized throughout the 5 weeks of experimentation.

\section{Enzyme assay}

$\mathrm{CAD}$ activity was constant for 3 weeks, and then fell in the following weeks for the control plants (Fig. 1A). When plants were inoculated with Glomus mosseae, higher CAD activity was observed 2 weeks after inoculation. Values then decreased during weeks 3, 4 and 5 to reach control values.

$\mathrm{PO}$ activity was constant during the first 3 weeks in the control plants. It then increased during the following weeks. The PO activity of inoculated plants was higher after 2 weeks, de creased at week 3 and then increased again (Fig. $1 \mathrm{~B}$ ).

Two weeks after inoculation, the first contact of the fungus with the root cortex occurred. CAD and cell wall-bound peroxidase activity peaks were observed in rubber seedling roots by this time. Spanu and Bonfante-Fasolo (1988) observed a similar increased peroxidase activity on Allium porrum inoculated with Glomus versiforme. Observed peaks of enzyme activity were related to first penetrations of mycorrhizal fungus in our experiment.

\section{Lignin contents}

Lignin percentage in inoculated plants was higher than in control plants 2 weeks after inoculation (Fig. 1C). No significant difference was observed between inoculated and control plants for the other time measurements.

Lignin deposition and peroxidase activities increased with time while CAD activity decreased. 

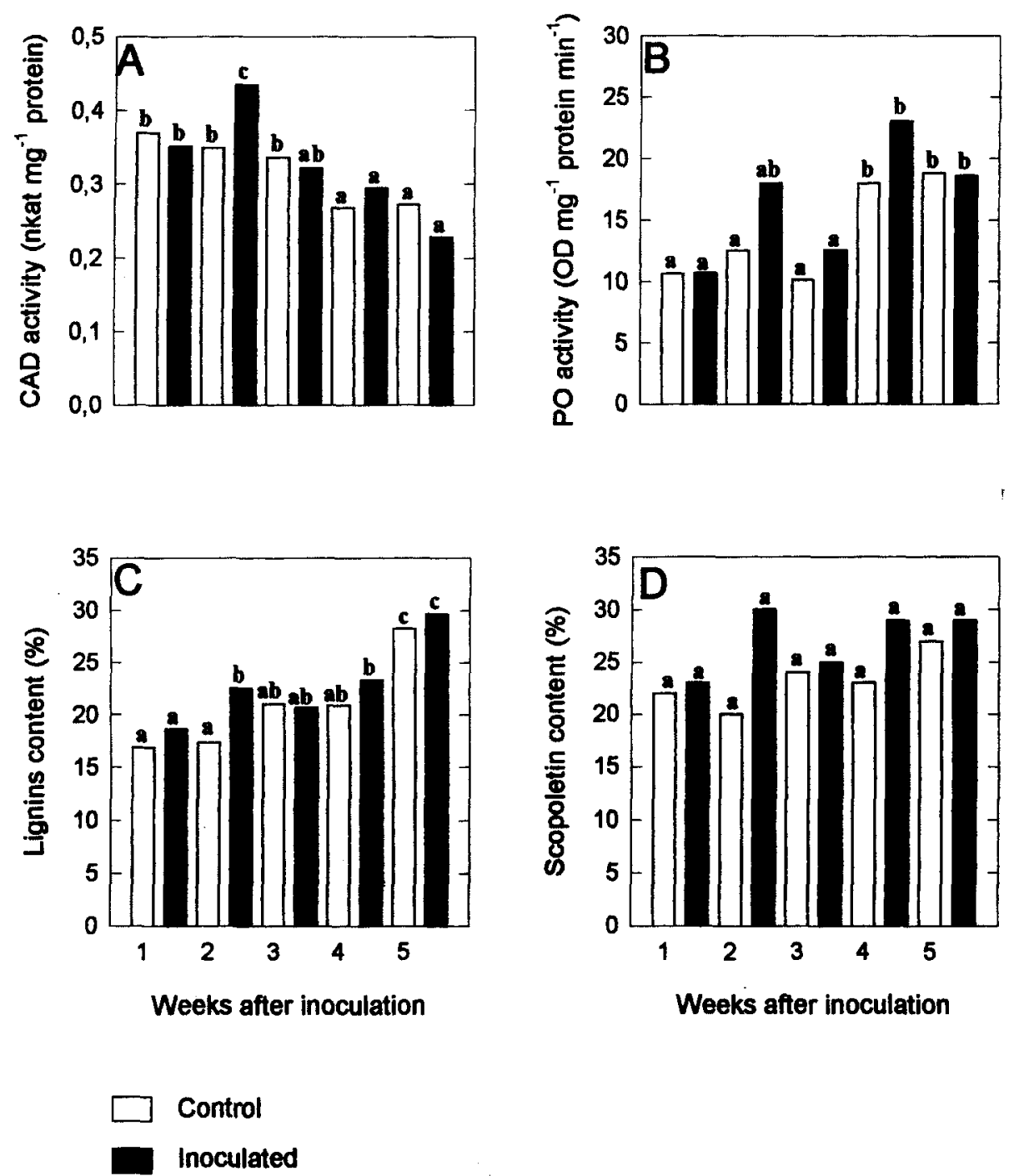

Fig. 1: Enzyme activities, and lignin and scopoletin contents in inoculated and control root tissues of rubber trees during the first 5 v.eeks after inoculation. A: CAD activity; B: PO activity; C: lignin percentage; D: scopoletin percentage. Values are the mean of 3 replications of 4 measurements. Means with the same letter are not different by Scheffe's test $(p<0.05)$.

\section{Scopoletin quantification}

A blue fluorescence was localized for all of the samples at the same spot of the commercial scopoletin, under UV viewing. The $R_{f}$ value in butanol : acetic acid : water was 0.90 and the $R_{f}$ value in acetic acid was 0.22 , as previously described in rubber tree leaves by Garcia et al. (1995). The extract was identified by spectral absorption from 240 to $400 \mathrm{~nm}$ compared with commercial scopoletin. No significant difference was observed between inoculated and control plants (Fig. $1 \mathrm{D})$. Hence, scopoletin was constitutively present in rubber seedling roots. However, no scopoletin accumulation was observed during the first penetration of the AM fungus. Scharff et al. (1997) reported no detectable increase in the phytoalexin levels of mycorrhizal soybean roots.

\section{Statistical analysis}

ANOVA showed an inoculation effect on all of the measurements of PO activity and lignin percentage (Table 1). Sam-

Table 1: Main factors and interactive effects of inoculation (control and inoculated) and sampling time (1 to 5 weeks) of CAD and PO activities, and lignin and scopoletin contents (ANOVA results).

\begin{tabular}{lllll}
\hline & CAD activity & PO activity & $\begin{array}{l}\text { Lignin } \\
\text { content }\end{array}$ & $\begin{array}{l}\text { Scopoletin } \\
\text { content }\end{array}$ \\
\hline Inoculation (I) & $\mathrm{NS}$ & $\mathrm{F}_{1,20}=4.4^{*}$ & $\mathrm{~F}_{1.20}=8.6^{* *}$ & $\mathrm{NS}$ \\
Sampling time (T) & $\mathrm{F}_{4.20}=15.9^{* *}$ & $\mathrm{~F}_{4.20}=9.0^{* *}$ & $\mathrm{~F}_{4.20}=64.0^{* *}$ & $\mathrm{NS}$ \\
$\mathrm{I} \times \mathrm{T}$ & $\mathrm{F}_{4.20}=3.1^{*}$ & $\mathrm{NS}$ & $\mathrm{F}_{4.20}=3.2^{*}$ & $\mathrm{NS}$ \\
\hline
\end{tabular}

NS: not significant; $*: p \leq 0.05 ;{ }^{* *}: p \leq 0.001$. 
pling time greatly influenced the variations between the various parameters except for scopoletin contents $(P<0.05)$. CAD activity and lignin percentage showed conjugate effects of inoculation and sampling time.

Hence, as reviewed by Gianinazzi-Pearson (1996) and AzcónAguilar and Barea (1996) on other plant-AM fungus models, when mycorrhizal symbiosis initiates between $H$. brasiliensis and $G$. mosseae, a weak, transient uncoordinated activation of inducible defence responses occurs that differs from the response elicited in plant-pathogen interactions.

\section{Acknowledgements}

The authors thank Christian Plenchette for the Glomus mosseae strain, Jacqueline Grima-Pettenati for helpful discussion on CAD assay, and the Michel'n Tire Company for Hevea brasiliensis seeds.

\section{References}

Azcón-Aguilar, C. and J. M. Barea: Mycorrhizas 6, 457-464 (1996).

BrADFORD, M. M.: Anal. Biochem. 72, 248-254 (1976).

Codignola, A., L. Verotta, P. Spanu, M. Maffei, S. Scannerini, and P. Bonfante-Fasolo: New Phytol. 112, 221-228 (1989).

De Jaegher, G.: Thesis Univ. Clermont-Ferrand II, 186 p. (1986).

De Jaegher, G., N. Boyer, and T. Gaspar: Plant Growth Regul. 3, 133-148 (1985).

Dixon, R. A., M. J. Harrison, and N. L. Paiva: Physiol. Plant. 93, 385-392 (1995).

Garcia, D., C. Sarter, J. J. Macheix, and J. D'Auzac: Physiol. Mol. Plant Pathol. 213-223 (1995).
Gianinazzi-Pearson, V.: Plant Cell 8, 1871-1883 (1996).

GiesemanN, A., B. BieHL, and R. Lieberei: J. Phytopathol. 117, $373-376$ (1986).

Harrison, M. J. and R. A. Dixon: Mol. Plant-Microbe Interact. 6, 643-654 (1993).

Hewitr, E. J.: Tech. Comm. 22 ( $2^{\text {nd }}$ edition revised), Commw. Agric. Bur., London, 430-435 (1966).

KIRK, T. K. and J. R. Oвst: Meth. Enzymol. 161, 87-101 (1988).

Mabry, T. J., K. R. Markham, and M. B. Thomas: Springer-Verlag, New York, USA (1970).

Monties, B.: In: Dey, P. M. and J. B. Harborne (eds.): pp. 113157. Academic Press, New York (1989).

Morandi, D., J. A. Bailey, and V. Gianinazzi-Pearson: Plant Pathol. 24, 357-364 (1984).

Nicole, M. R., J. P. Geiger, and D. Nandris: In: Blanchette and Biggs (eds.): pp. 181-206. Springer Series in Wood Science, Ed. Timell, Berlin (1992).

- _ - : Eur. J. For. Pathol. 16, 37-55 (1986).

Phillips, J. M. and D. S. Hayman: Trans. Brit. Mycol. Soc. 55, 159-161 (1970).

Sarni, F., C. Grand, and A. M. Boudet: Eur. J. Biochem. 139, 259-265 (1984).

Scharff, A. M., I. Jakobsen, and L. Rosendahl: J. Plant Physiol. $151,716-723$ (1997).

Schwob, I., M. Ducher, H. Sallanon, and A. Coudret: Trees Struct. Funct. 12, 236-240 (1998).

Smith, C. J.: New Phytol. 132, 1-45 (1996).

Spanu, P. and P. Bonfante-Fasolo: New Phytol. 109, 119-124 (1988).

Volpin, H., Y. Elkind, Y. Okon, and Y. Kapulnik: Plant Physiol. 104, 683-689 (1994). 